Article

\title{
Who We Are Is What We Believe? Religion and Collective Identity in Austrian and German Immigrant Integration Policies
}

\author{
Astrid Mattes \\ Department of Political Science, University of Vienna, 1010 Vienna, Austria; E-Mail: astrid.mattes@univie.ac.at
}

Submitted: 13 September 2016 | Accepted: 15 December 2016 | Published: 28 March 2017

\begin{abstract}
Immigrant integration is a contested policy field in which boundaries of membership are drawn and re-negotiated whereby groups of immigrants are partially included and excluded. Building on the concept of collective identity and theories of boundary making, this paper illustrates how religion functions as a category to mark and fill notions of self and otherness. As several studies have shown, immigrants in Europe are increasingly addressed as Muslims, a development that also serves the promotion of a Christian 'us'. Focusing on Austria and Germany, two countries where this is especially observable, the paper outlines the functioning of religion as symbolic boundary. The empirical study on national integration policies demonstrates how - within the relational process of boundary drawing against Muslims-a Christian identity narrative is established, how it functions as a marker of unity and how it relates to liberal and secular notions. Results from the qualitative content analysis of governmental policy programs from 2005 onwards show different patterns of boundary drawing on religion and the way they shape and limit the possibilities of inclusion. To understand this development, we have to look at Christian-democratic policy-makers, who currently dominate the political struggle for the power to define features of collective identity in immigrant integration policies.
\end{abstract}

\section{Keywords}

boundary making; collective identity; Christian-democrats; immigrant integration; Islam; religion

\section{Issue}

This article is part of the issue "International Migration and Ethnic Integration", edited by Yaojun Li (University of Manchester, UK) and Anthony Heath (University of Oxford, UK).

(C) 2017 by the author; licensee Cogitatio (Lisbon, Portugal). This article is licensed under a Creative Commons Attribution 4.0 International License (CC BY).

\section{Introduction}

As shown by various studies, Islam and Muslims have become 'the other' in European immigrant integration debates (Allievi, 2005; Grillo, 2010; Modood, 2009). The literature gives different explanations for the difficulty European societies experience with the integration of their Muslim populations. Within a broad spectrum of approaches, I identify four distinctive lines of argument. Some authors argue that Europe is essentially Christian, 'deeply rooted in a Christian tradition' and that Islam is therefore problematized in discourses on immigrant integration (Zolberg \& Woon, 1999). In this view, the conflict comes down to the unwillingness to adapt predominantly Christian settings to religious pluralism and the refusal to include another religion into Christian self- perception. Conversely, other authors argue that Europe is essentially secular (Cesari, 2009; Foner \& Alba, 2008), in fact the 'most deeply secularized of all corners of the globe' and the 'real issue in the Islam challenge is a vitally felt religion meeting a thoroughly non-religious (but not other-religious) environment' (Joppke, 2013, p. 611). This argument sees the Muslim presence (and the religious demands it might entail) as a challenge to the now essentially secular Europe. A third argument focuses on the essentially liberal identity of European states and the illiberal threat Islam might pose to it (Hansen, 2011). While similar to the idea of a secular Europe, this line of argument does not read the presence of a vibrant religion per se as a problem but the illiberal ideas it is argued to transmit. A fourth view on the problematization and the othering of Islam argues on a meta-level, 
seeing 'Muslim' as a racialized category to name a 'visible other' to white Europeans in a 'colour-blind' Europe (El-Tayeb, 2011, p. 16). This way of thinking would view the three other arguments as proof of the underlyingessentially racial-boundary at play. All these arguments have in common that they link the problematization of Islam to the constitution of the European self. This follows the logic of identity politics in which unity is produced by pointing out what is 'not us'. While the portrayal of Muslims and Islam as problematic is common to most European immigrant integration debates, there is less clarity about the unifying elements of the perceived 'us'. To put it bluntly: Are we all Christian, are we all secular, are we all liberal or are we just white?

Much scholarly attention has been paid to the application of 'Muslim' as a category of other-identification in immigrant integration debates and its exclusionary implications, but fewer studies analysed the resulting construction of the 'us' that is necessarily implied (valuable insights can be found in Brubaker, 2010; Eder, 2006; Korteweg \& Yurdakul, 2014). Several authors have noted a new emphasis on Christianity as one particular aspect of this 'us' in European immigrant integration policies (Joppke, 2013; Modood, 2012). However, there is little understanding of this addressing of religion, how it functions as a marker of unity and how it relates to liberal and secular self-perceptions. The sole focus on the exclusion of an out-group obstructs any understanding of the underlying controversy over what makes up a collective identity. Not taking into account the political attempts to shape these perceptions, ignores ongoing power struggles over who 'we' are and what might or might not be in 'our' interest.

On that score, this paper focuses on the ways in which religion is involved in collective identities articulated in the context of immigrant integration. An empirical case study on governmental immigrant integration policies in Germany and Austria looks at the construction of symbolic boundaries that draw on religion as a marker for self and otherness. During the periods of observation (2005-2009 in Germany, 2008-2013 in Austria) both countries developed immigrant integration policy programs at national level, which were predominantly shaped by Christian-democratic policy makers (CDU/CSU in Germany, ÖVP in Austria). The analysis shows how Christianity is related to liberal and secular ideas almost to the same extent as Islam is assumed to oppose them. In the relational process of boundary drawing, Muslims (constructed as a homogenous group) are continuously portrayed as illiberal in their religious beliefs and practices while Christianity is constructed as an essential marker of unity in a variety of ways. Here, Christiandemocratic parties might have found a way to overcome their struggle to successfully combine a Christian identity with a liberal democratic setting in increasingly secular societies. Rather than viewing this new emphasis on Christianity as a religious conflict, as a response to multiculturalism or as a sign of liberal disorientation, we can understand it as an expression of a political ideology Christian-democratic policy makers foster.

\section{Collective Identity and Boundary Making in Immigrant Integration Policy}

Immigrant integration policies produce membership boundaries through a notion of 'into what' immigrant populations are supposed to be integrated. As many authors have pointed out, it is the very idea of integration itself that provokes the issue of a common selfperception (Joppke, 2013; Korteweg \& Yurdakul, 2014). This preoccupation with characteristics of a perceived unity allows policy makers to create and position narratives about 'us'. Consequently, we can understand immigrant integration policy debates as 'negotiations over how best to craft a shared national identity in a social context transformed by immigration' (Korteweg \& Triadafilopoulos, 2013, p. 115). National identity mostly revolves around the idea of a common past, ancestry and culture of the people living in a certain territory (Guibernau, 2004, p. 126). Viewing nations as 'imagined political communities', national identity has to be seen as a permanent discursive process resulting in a kind of habitus which people 'internalize through socialization' (De Cillia, Reisigl, \& Wodak, 1999, p. 153). It would be a foreshortened view to equate the aspects of identity promoted within immigrant integration policies with national identities. They are better understood as collective self-identifications, which is to 'identify oneself and others at the same time: to speak not just of but for others, to subsume others, along with oneself, into a collective "we"” (Brubaker, 2013, p. 2).

I use the term collective identity, as the construction of sameness does not necessarily rely on the notion of nation but mostly promotes a collective identity that is embedded in the European context as well as in particular national ones. Complementary to the 'Europeanization of exclusion', which subsumes the extensively researched othering of Islam across Europe (ElTayeb, 2011, p. 23), there might be a Europeanization of inclusion, which cannot be observed if promoted identities are analysed as nationally bound.

The promotion of collective identity serves the creation of a majority, as well as the making of minorities (Wimmer, 2013), both shaped by the 'delineation of "us" and "not us"' (Zolberg \& Woon, 1999, p. 8). Theories of boundary making view this as a relational process whereby in-groups and out-groups form around boundaries. Scholarship on boundaries covers a multitude of micro- and macro-social and socio-political categorization processes (see Pachucki, Lamont, \& Pendergrass, 2007). Interested in how religion becomes a feature of collective identity, this paper's focus lies on categorization in governmental policy programs as a specific aspect of symbolic boundary formation.

Symbolic boundaries are 'conceptual distinctions' social actors make to 'separate people into groups and gen- 
erate feelings of similarity and group membership' (Lamont \& Molnár, 2002, p. 168). State institutions, such as governments, are in a dominant position to make their preferred distinctions 'politically relevant, publicly acknowledged and culturally legitimate' (Wimmer, 2013, p. 64). In the literature on boundary formation, symbolic boundaries are differentiated from social boundaries, which manifest in institutions and limit access to resources for certain groups (Bail, 2008). While social boundaries are reinforced and made salient using discrimination, collective organization and physical violence, means of symbolic boundary making include symbolic actions and discursive practices.

This paper analyses symbolic boundary formations, which function along distinct modes. Andreas Wimmer describes these modes as mostly building on existing group concepts that might change through processes of contraction or expansion, transvaluation, positional moves or boundary blurring (2013, p. 57). Boundaries shift (contract or expand) when terms for membership and non-membership are redefined, narrowing or widening the set of accepted attributes. Transvaluation occurs, when the normative order of a stratified system changes. Individual or collective positional moves might allow boundary crossings. However, bright boundaries can only be overcome by giving up distinctive elements of one's identity as they require assimilation in its strictest sense (Alba, 2005) and persist despite individual crossings (Barth, 1998). When boundaries get blurred by contrast, the in-group and its structures change. Former characteristics of the out-group become accepted within the in-group, the overlapping of previously mutually exclusive identity markers and multiple memberships are tolerated (Korteweg \& Yurdakul, 2014). While especially Wimmer's modes of boundary making are more complex and comprehensive, the general applicability to categorization processes makes theories of boundary making a useful analytical tool to understand how institutions shape religion as a notion of difference.

\section{Religion and Collective Identity}

In terms of the composition of collective identities promoted in European immigrant integration policies, there is broad agreement on two aspects: First, Muslims have become 'the other' to European immigrant integration debates, which strongly relates to the securitization of this policy field and the simultaneous regulation of Islamic religion within it (Cesari, 2009). Second, there is a widespread acceptance that liberalism has become a cornerstone of the 'us' that collective identities refer to (Triadafilopoulos, 2011). The uniting element we can observe in most European integration policies of recent years is a postulated value consensus among the established population (Adamson, Triadafilopoulos, \& Zolberg, 2011). This consensus is mostly presented as building on a set of liberal norms and the upholding of human rights. Conversely, the addressees of immigrant integra- tion policies are characterized as not having internalized this set of norms (yet). This characterization of an outgroup, marked by illiberal ideas (or the insufficient support of liberal ones) happens concurrently with conceiving immigrant populations as Muslims.

On the other hand, a renewed emphasis on Christianity has been observed by several authors but is rarely discussed more closely. Tariq Modood views this new emphasis as a 'response to the challenge of multiculturalism' in the light of 'the primacy given to religion as the basis of identity, organization, political representation, normative justification, etc.' (2012, pp. 139-140). The problematization of Muslims is-as demonstrated by Riem Spielhaus (2011) - not self-evident, nor is it simply related to the presence of believers. Equally, I suggest, the new emphasis on Christianity cannot be viewed as a selfevident reaction to the presence of Muslims in Europe and the primacy that is given to Islam. It is perfectly possible to encounter a religiously defined other with a nonreligious line of argument.

Liberalism is however, insufficient to promote a specific national identity, as the universal character of liberal norms limits their scope to build a collective identity on particularistic elements (Joppke, 2008, p. 536). Christian Joppke therefore concludes that the new emphasis on Christianity is an attempt to capture a particularistic identity element $(2008$, p. 540$)$. This is unconvincing: a Christian collective identity is neither particularisticChristianity is not French, Austrian or German, it is just not Muslim-nor easily combined with liberal norms. Joppke addresses this issue in a later paper by calling Christianity and liberalism 'different words for the same thing observed over time' and attesting the term Christian to function as 'a code word for national particularism' (2013, p. 612). This ignores not only the vital theoretical debate about the relation of Christianity and Liberalism (Dombrowski, 2014; Gillespie, 2014; Laborde, 2013; Maffettone, 2014), but also the lively diversity of religious and secular political positions that exist within Europe and compete in many policy fields. In a way, this approach also contributes to the simplifying dichotomy of 'good religion/bad religion' many authors speak of, when religion is endorsed by state actors as long as it is useful to their own agenda (Wilson \& Mavelli, 2014, p. 19).

Rather than viewing the new emphasis on Christianity just as a quasi-automatic response to the challenge of multiculturalism, as a search for particularistic identity elements of disoriented liberal states or even a religious conflict between Islam and Christianity, I suggest understanding it as the result of a contested process of competing sets of possible identity elements. The new emphasis on Christianity is primarily the expression of a political struggle for the power to define features of collective identity.

I will argue that Christian-democratic parties are pushing for this new emphasis on Christianity to solve their internal dilemma with proximity and distance to religion. Parties of the radical right use anti-Islamic ideas to pro- 
mote a nationalist and exclusionary notion of 'us'. Socialdemocratic policy-makers have the tendency to disregard the role of religion (and culture) for immigrant integration (Laurence, 2013), instead focusing on socio-political aspects as markers for equality and difference (Scheffer, 2011). Christian-democratic parties, however, are seen as traditionally concerned with 'philosophical, ethical and, in a broader sense cultural issues' (Dierickx, 1994, p. 17).

\section{Immigrant Integration, Religion and Christian-Democrats in Austria and Germany}

Immigrant integration programs from Austria and Germany are the empirical basis for this case study on religion as a marker for self- and otherness. The two countries share similar migration histories and resemble each other in their approach towards integration (Koopmans, 2005). Up until the 1990s, despite significant histories of immigration, politicians in both Germany and Austria widely refused to identify their country as a country of immigration. Like other countries that installed guest worker regimes, Germany and Austria neglected badly needed integration policies for long-term residency. Rather, measures were limited to the labour market while return migration was equally fostered (Bommes \& Kolb, 2012). Not until the turn of the millennium did integration issues finally climb up on the governmental political agenda. Comprehensive and systematic development of integration policy in Germany began after 2005 under a grand coalition government. Similar efforts at national level in Austria only started in 2008 (for a detailed overview of both countries immigrant integration policy development see Zincone, Penninx, \& Borkert, 2011). The empirical analysis focuses on this period in which immigrant integration became a more closely defined and actively addressed policy field in both states.

Over the period of this project, Christian-democratic parties shaped both countries' immigrant integration policies. For Austria, it can be reasonably assumed that it was primarily the Austrian People's Party (ÖVP) that shaped outputs from 2000 onwards: Holding the relevant office (Ministry of Interior until 2011, State Secretariat for Integration from 2011 to 2013) can be seen as exceptionally influential in that particular policy field. In Germany during the empirical study period (2005-2009), Christian Democratic Union (CDU) held the governmental offices in charge of immigrant integration policy (Ministry of Interior, Federal Chancellery). Therefore this papers' findings are also limited to this party family.

Religion is a contested issue within those parties. In Germany, this became particularly evident during the 'Leitkultur' debate from 2000/01 onwards (Manz, 2004). This debate, in which CDU politicians picked up a term coined by the political scientist Bassam Tibi (1998), addressed the role of Christianity for collective identity. This was also contested within the party and it became one of many occasions when the meaning of the ' $C$ ' in the party's name was discussed controversially. German Chancellor
Angela Merkel emphasized the importance of Christianity in various contexts, from demanding migrants to 'accept' Christian values (Der Spiegel, 2010) to the call on young party members to be more 'excited' about their Christian beliefs (Schwarze, 2010). The role of religion for and within the Austrian ÖVP is also ambivalent but less openly debated. When the party was re-established after World War II, they did not call themselves Christian to address a wider electorate and to demonstrate distance to the pre-war experience of Catholic authoritarianism (Binder, 2001). Throughout its post-war history, emphasizing conservative values and the role of Christianity was frequently used to counter criticism on neoliberal economic policies (Müller, 2014, p. 245).

Concerning state-religion relations, Austria and Germany are classified as 'systems of shared tasks' (Minkenberg, 2002), characterized by the exclusive collaboration of state institutions and religious communities acknowledged in law. These selected communities enjoy tax benefits, state-funded religious education in public schools, special legal protection and other privileges. In Austria, the Catholic Church is in a particularly dominant position. Over sixty per cent of the Austrian population are members of this church and Christianity is granted an outstanding role in the public sphere (e.g. crucifixes in classrooms). Because of its history as a multi-ethnic empire, Austria officially recognized Islam in 1912, following the annexation of Bosnia-Herzegovina. A state-recognized Islamic religious community was then established in 1979, long before Islam became a politicized issue. Many aspects of institutional embedding which are disputed in other European countries are regulated and not very contentious (Mattes \& Rosenberger, 2015).

More than Austria, Germany is characterized by a distinct internalization of intra-Christian religious pluralism. Two Christian churches of almost equal size (Catholic and Protestant) dominate the religious landscape and, similar to Austria, enjoy the status of statutory bodies under public law. The state recognition of Islamic communities is a contentious issue that is not limited to religion politics but closely related to immigrant integration. The German Islam Conference (Deutsche Islamkonferenz, DIK) was established in 2006 to address both the institutional embedding of Islamic religious communities and the integration of Muslims in Germany (RosenowWilliams, 2012). Participants included state authorities, Muslim representatives and individuals, as well as experts from academia and practice. In the course of the DIK it became clear that the initial hope for state recognition held by Islamic associations was only a distant prospect. While the DIK was at first scheduled as a threeyear process, its mandate was renewed for the third time in 2014.

\section{Methods and Material}

Immigrant integration policies from Austria and Germany build a case in which processes of boundary 
drawing on religion can be identified. The empirical work builds on a qualitative content analysis of immigrant integration policy documents. Two central research questions where addressed: 1 ) How are different religions constructed in immigrant integration policies? and 2) What is the relationship between these constructions and the collective identity promoted in immigrant integration policies? As immigrant integration policies developed at different tempos, it is more accurate to investigate periods surrounding a key event than choosing a concrete time span. The period of analysis starts with the initial development of national policy strategies and is limited to one term in office of the respective government. This allows to investigate a timespan in which most influential factors stayed constant and varied party strength did not affect policy outputs. German integration policy programs analysed cover the period between November 2005 and October 2009, Austrian policies were analysed from December 2008 to November 2013. During these periods, each government issued eight major documents (see Table 1) covered in this analysis. The data material also includes selected information material, campaigns and press releases that explicitly address the issue of collective identity.

In the initial round of coding, text passages that draw on religion in the context of collective identity have been identified. A coding scheme, derived from relevant literature on symbolic boundary formation (Alba, 2005; Bail, 2008; Korteweg \& Yurdakul, 2014; Lamont \& Molnár, 2002; Wimmer, 2013) was used to perform a qualitative content analysis using semi-structured coding (Mayring, 2008). The coding of categorization practices ('defining relevant groups' and 'defining who belongs', Wimmer, 2013, p. 46) and types of boundaries (as discussed above) allowed for the identification of recurrent elements. After several rounds of coding, clusters of similarly structured elements were identified, out of which three patterns of relating religion to collective identity emerged.

\section{Analysis and Discussion: Three Patterns of Religion as a Symbolic Boundary}

Below I will present and discuss three patterns of religion as a symbolic boundary identified in the empirical case study. Direct quotes from the data material (translated by the author) are used to exemplify the results of the analysis. The subsequent discussion focusses on Christian-democratic parties as drivers of the observed emphasis on Christianity that mostly occurs in relation to Islam. Other minority religions by contrast, are hardly ever referred to in the policy documents analysed.

\subsection{Muscular Liberalism}

This first pattern is particularly relevant because it is not an alternative to the other patterns identified, but mostly works as an underlying structure. The categorization practice in this pattern defines the majority as uni- fied by liberal values. Here, religion is not a feature of collective identity. The out-group by contrast is named as Muslims, marked by lacking willingness or ability to implement liberal norms.

'[I]t is important to communicate Austrian fundamental values and rights and install a sense of belonging among Muslims.' (Bundesministerium für Inneres [BMI], 2012, p. 24)

Patterns like this have been discussed in the literature referring to 'muscular liberalism', which is based on the idea 'that it is the business of a liberal state to produce liberal individuals and promote a liberal way of life' (Modood, 2012, p. 143). Muscular Liberalism is not necessarily linked to religion and can be found in both Germany and Austria. In Germany, however, this pattern is most common in the context of the DIK. Muslim representatives had to profess their commitment to liberal norms throughout the process. The location of these claims of muscular liberalism in the context of the DIK links questions of shared values structurally to religion and to Islam in particular. Identity narratives are rarely found in general integration policy documents, while 'collective identity and shared values' is one of four core subjects of the DIK, almost like an outsourcing of value debates.

The boundary drawn here does not demarcate a clear in-group. Liberal is the only attribute the majority shares; no categories of difference are applied. The out-group however, is described as 'Muslims' and characterized as illiberal. This limits the possibilities of boundary crossing to individual positional moves. A formal 'commitment to the value system' by Muslim representatives is requested to allow for boundary blurring and the acceptance of the former mutually exclusive combination of 'liberal' and 'Muslim': Still, as the following statement from German National Integration Plan shows, boundaries might be uphold despite a given commitment:

'[T] $T$ he committee pointed out that it is now crucial to connect the given commitment to the value system of the Basic Law to issues of everyday life, such as equality of men and women and unlimited school attendance of children from Muslim families.' (Deutsche Bundesregierung, 2007, p. 207)

\subsection{Christian Ancestry}

Within the 'Christian Ancestry' pattern, doubts about the extent to which Muslims are able or willing to accept liberal and secular structures are opposed with the construction of both secularism and liberalism as a historical product of Christianity and therefore insolubly linked. This takes two forms:

In the first argument, Christianity is given an active role in the promoted collective identity as secular structures are attributed to this religion. 
Table 1. Overview data material.

\begin{tabular}{|c|c|c|c|c|}
\hline & Austria & & Germany & \\
\hline 2006 & & & $\begin{array}{l}\text { - 'Declaration of Intent', } \\
\text { Federal Government } \\
\text { - Opening Declaration of the } \\
\text { German Islam Conference }\end{array}$ & $\sigma \stackrel{D}{\stackrel{D}{n}}$ \\
\hline 2007 & & & - National Integration Plan & 更々市 \\
\hline 2008 & $\begin{array}{l}\text { - Expert Analysis on Integration } \\
\text { 'Gemeinsam kommen wir zusammen' }\end{array}$ & 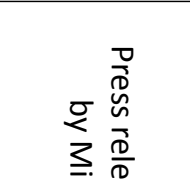 & $\begin{array}{l}\text { - National Integration Plan, } \\
1^{\text {st }} \text { Progress Report } \\
\text { - German Islam Conference, } \\
3^{\text {rd }} \text { Plenum Report }\end{array}$ & 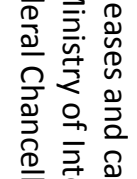 \\
\hline 2009 & - Survey 'Integration in Austria' & 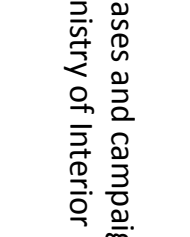 & $\begin{array}{l}\text { - 'Three years German Islam } \\
\text { Conference' } \\
\text { - German Islam Conference, } \\
\quad 4^{\text {th }} \text { Plenum Report } \\
\text { - Survey 'Muslim Life in Germany' }\end{array}$ & 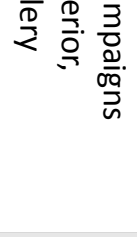 \\
\hline 2010 & - National Action Plan for Integration & $\stackrel{\sigma a}{7}$ & & \\
\hline 2011 & $\begin{array}{l}\text { - Work Program Experts Council Integration } \\
\text { - Annual Progress report on the National } \\
\text { Action Plan for Integration }\end{array}$ & 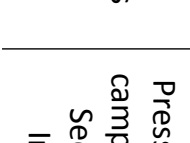 & & \\
\hline 2012 & $\begin{array}{l}\text { - Annual Progress report on the National } \\
\text { Action Plan for Integration } \\
\text { - Report on the Dialogue Forum Islam }\end{array}$ & 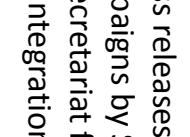 & & \\
\hline 2013 & $\begin{array}{l}\text { - Annual Progress Report on the National } \\
\text { Action Plan for Integration }\end{array}$ & 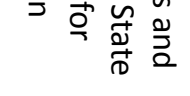 & & \\
\hline
\end{tabular}

'The German legal framework for the relation between the state and religious communities developed in the historical confrontation with Christian churches.' (DIK, 2009, p. 264)

The historical role of Christian churches is applied as a boundary against Islam in the context of the DIK. Continuous references to the historic role of Christian churches in the development of a secular state order portray Christianity as a religion that is already fulfilling such secular standards and has even co-founded them. Islam is viewed as opposed to these values. This relates to Talal Asad's view on secularism, as the effect of heterogeneous power relations, rather than as a substantial concept. As he argues, certain constructions of the secular are reproduced against Muslims, constructing them as 'external to the essence of Europe' (2003, p. 151).

In the second argument that works within this pattern, the description of Muslims as potential danger to liberal values is contrasted with the construction of these universal ideas as derived from Christianity and therefore essentially linked to it. Here universal values are portrayed as derived from Christian scriptures, Christian theology or Christian ethics, and the normative foundations of contemporary Europe are attributed to Christianity.

An example for such boundary construction can be found in the preamble of an early Austrian policy program:
'The following discussion will show that the problem of integrating foreigners predominantly concerns members of the Islamic culture, to a lesser extent also those of other (for example African or Asian) cultures.' (BMI, 2008, p. 18)

This statement is followed by a discussion of 'Austrian values', a listing of liberal norms. On the basic principle of equality the document states:

'The principle of equality derives from statements of the Old and especially the New Testament, that all men are equal before God.' (BMI, 2008, p. 20)

Despite a reference to the French Revolution as another source for the principle of equality that follows this statement, a binary opposition is constructed between liberal democracy, which is portrayed as a result of Christian belief, as part of 'us', and a certain idea of Islam, which is characterized by its non-compatibility with universal norms. Both membership and non-membership are defined on religious grounds. However, only few paragraphs in the analysed material are so illiberal in character. In general, references to Christianity are more carefully embedded in the discussion of collective values and identity. This quote from then Minister of the Interior in Germany, Wolfgang Schäuble, expresses this development: 
'[W]e have expectations of Muslims. Following the German legal and moral order, we understand the way towards a thriving coexistence as a process in which cultural and religious differences have to be acknowledged, but also in which the complete acceptance of liberal-democratic basic principles is required as a precondition....Within this order-which is shaped by Christian ethics, this has to be said-Islam has to find its place.' (DIK, 2009, p. 15)

In different forms, this pattern of boundary drawing subsumes the construction of a Christian ancestry to which Islam and Muslims, as the other, are opposed. Christianity, Christian norms or Christian ethics are portrayed as a cultural tradition or a heritage, rather than an actual religion. Joppke calls this a 'demotion of "religion" to the status of "culture"'. In Joppke's argument this promotion of religion through a demotion to culture makes it less of a violation of the neutrality mandate liberal democratic states ought to hold (2013, p. 606). While Christianity is treated as a cultural element, it is debateable to what extent this treatment is a demotion and not just a decoy or even an enhancement. It builds on the pattern of muscular liberalism that merges with a 'neutralized' Christianity. This only relates to a historic development but lacks any reference to believers, churches or religious practice. Tariq Modood speaks of a 'secular Christian', 'analogous to the term 'secular Jew' to describe someone of Jewish descent who has a sense of Jewish identity but is not religiously practicing and may even be an atheist' (2012, p. 142).

Yet this apparently secular Christianity functions to keep Islam outside of the bright boundary of collective identity. More than in the pattern of muscular liberalism, this boundary defines members of the in-group. Compared to the pattern of muscular liberalism, this is a contracting boundary shift as membership is now defined narrower as determined by Christian ancestry.

\subsection{Universal Religion}

In this pattern unwanted, illiberal and radical behaviour is attributed to 'wrongly understood' religion (then State Secretary for Integration in Austria Sebastian Kurz in Kathpress, 2011) as opposed to a universal religion that reinforces liberal values. No longer is Islam explicitly the marker for an out-group and Christianity the ingroup characteristic but a religious community ('we') is opposed by illiberal people who misinterpret religious concepts.

This pattern of boundary drawing is particularly prominent in Austrian policy documents, e.g. in the statement below from the 2011 Integration Report:

'A major factor in the integration debate is the question of religious practice.... For acknowledged religious communities, there is a need to examine how privileges granted by the state can be utilized to support integration and in turn to impede or avoid behaviour, which is not in accordance with the constitutional laws, under the "cloak" of religion.' (Staatssekretariat für Integration, 2011, p. 13)

Religion, portrayed as generally positive and compatible with universal norms, is differentiated from practices and beliefs described as happening 'under the cloak of religion'. Overall the positive evaluation of religion's ability to promote values comes to the fore, as in the following quote from Sebastian Kurz, on the topic of (Islamic) religious education in public schools:

'I believe that religion is very important to people in principle, that values are something important and religion is a good approach to examining personal fundamental values.' (Die Presse, 2011)

This involvement of universal religion in immigrant integration is even recommended to influence other policy fields:

'The Expert Council for Integration recommends a broad discussion among state actors, researchers and religious authorities about the role of religion in the public and private spheres. The findings of this process should not only influence religious education and ethics lessons in school, but should also be reflected in labour law, regional development and other legal issues.' (BMI, 2013, pp. 25-26)

This pattern of boundary drawing on religious grounds is an enhancement of religion. 'Universal religion' as part of the collective identity promotes a shared value basis in which the religious, not the secular, is seen as universal. My usage of this term draws on Lori Beaman's concept of the 'will to religion'. Here she discusses a more general trend towards increasing the relevance of religion in various aspects of public life and its consequences. Beaman describes universal religion as 'Christianity's transmutation as representing universal values', able to include a spectrum of religious traditions but remaining 'fundamentally Christian in its shape' (2013, pp. 149151). While this opens up a possibility for the inclusion of Islam, at the same time it raises the questions of how to assess whether a religion is understood wrongly or rightly and who would be entitled to make this decision. Although integration policy documents do not name concrete examples, critical assessment of religion-as, for example, the Dialogue Forum Islam and its working group on 'gender relations', which aims to 'strengthen women's roles in community work' (BMI, 2013)-is limited to Islam and never involves illiberal aspects of Christianity. Islam and Christianity are not constructed in opposition but religion in general is understood as a positive, even necessary, part of Austrian society. A boundary is drawn between a collective identity of which religion is a central feature and some vague 'other' char- 
acterized as incompatible with liberal norms and 'under the cloak of religion'. We can understand universal religion as a boundary expansion: through an emphasis shift, it is no longer Islam in general that is associated with illiberal and therefore outgroup-characteristics but 'misconceived religion'. The boundary that is maintainedthe demarcation of misconceived religion, characterized as illiberal and problematic - is clearly used to address (some) Muslims.

All three identified patterns of boundary drawing (see Table 2) can be observed in both Germany and Austria, yet they are unequally distributed between the cases. In Germany, many integration policy documents avoid addressing collective identity and common values beyond references to the Basic Law as a set of universal norms. This focus on the constitution as a point of reference for collective identity, which is much less common in Austrian documents, brings to mind the concept of 'constitutional patriotism' (Habermas, 1991; Sternberger, 1990). Unlike the Austrian constitution, the historic development of the German Basic Law holds a significant meaning for post-war German society (Kommers, 2012). Instead, the German debate on collective identity is mainly outsourced to the Islam Conference and therefore structurally connected to religion. The out-group here becomes defined a priori by the specific setting. The muscular liberalism pattern, whereby a boundary between liberal values and Muslims as an illiberal other is drawn, can be found within the DIK documents and beyond. The Christian ancestry pattern, which connects the liberal self to Christianity by 'secularizing' it, is also common in German policy documents and in particular in DIK documents or general documents that refer to the DIK. The opposite is true of Austrian policy documents. The muscular liberalism pattern is as common as in German documents, although it is not expressed through references to the constitution. While Christian ancestry is less present than in German documents, the pattern of universal religion characterizes Austrian immigrant integration policy documents of the study period. This might be related to the relatively active role of religion that can be found in Austria beyond the field of immigrant integration policies (Avramopoulou, Çorbacioğlu, \& Sanna, 2012; Mattes \& Rosenberger, 2015).

\subsection{Two Christian-Democratic Parties Resolving a Common Dilemma?}

While differences between Austria and Germany are small, the similarities are striking. A new emphasis on Christianity, in form of Christian ancestry and universal religion has been observed in both countries. As actors behave strategically to shape boundaries in their interest (Wimmer, 2013, p. 205) I want to discuss the particular strategies of Christian-democratic policy-makers, who shaped the immigrant integration programs analysed.

Historically, Christian-democratic parties emerged somewhat in conflict with the political system they operated in and often functioned 'as interest groups within a system whose legitimacy the church continued to reject' (Müller, 2014). Early Catholic parties were not in favour of the democratic development of European nation states. Obviously, this anti-democratic attitude has given way to a positive assessment of the modern liberal state and is no longer a characteristic of today's Christian-democratic parties. The shift to a democratic and more liberal political orientation happened at the expense of a narrow Christian (Catholic) agenda (Van Hecke \& Gerard, 2004, p. 316). Early on in their history, Christian-democratic parties experienced close ties to the Catholic Church as restraining. Not only did the influence of church officials constrain political margins, but the parties' confessional character also narrowed their potential electorate. Christian-democratic parties found

Table 2. Patterns of religion as a symbolic boundary.

\begin{tabular}{|c|c|c|c|c|c|c|}
\hline & $\begin{array}{l}\text { In-group } \\
\text { characteristics }\end{array}$ & $\begin{array}{l}\text { Who } \\
\text { belongs to } \\
\text { in-group? }\end{array}$ & $\begin{array}{l}\text { Out-group } \\
\text { characteristics }\end{array}$ & $\begin{array}{l}\text { Who } \\
\text { belongs to } \\
\text { out-group? }\end{array}$ & $\begin{array}{l}\text { Type of } \\
\text { boundary }\end{array}$ & $\begin{array}{l}\text { Potential of } \\
\text { boundary } \\
\text { crossing }\end{array}$ \\
\hline Muscular liberalism & liberal values & $\begin{array}{l}\text { undefined } \\
\text { majority }\end{array}$ & illiberal & Muslims & $\begin{array}{l}\text { (potentially) } \\
\text { blurred }\end{array}$ & $\begin{array}{l}\text { collective: } \\
\text { commitment? } \\
\text { individual: } \\
\text { assimilation }\end{array}$ \\
\hline \multirow[t]{2}{*}{ Christian ancestry } & $\begin{array}{l}\text { liberal values, } \\
\text { determined by } \\
\text { Christian history }\end{array}$ & \multirow[t]{2}{*}{$\begin{array}{l}\text { secular and } \\
\text { Christian } \\
\text { majority }\end{array}$} & \multirow[t]{2}{*}{ illiberal } & \multirow[t]{2}{*}{ Muslims } & \multirow[t]{2}{*}{$\begin{array}{l}\text { bright, } \\
\text { contracted }\end{array}$} & \multirow[t]{2}{*}{$\begin{array}{l}\text { collective and } \\
\text { individual: } \\
\text { assimilation }\end{array}$} \\
\hline & $\begin{array}{l}\text { liberal values, } \\
\text { determined by } \\
\text { Christian theology }\end{array}$ & & & & & \\
\hline Universal religion & $\begin{array}{l}\text { values determined } \\
\text { by religions as } \\
\text { moral authorities }\end{array}$ & $\begin{array}{l}\text { religious } \\
\text { majority }\end{array}$ & $\begin{array}{l}\text { illiberal, 'under } \\
\text { the cloak of } \\
\text { religion' }\end{array}$ & $\begin{array}{l}\text { (some) } \\
\text { Muslims }\end{array}$ & $\begin{array}{l}\text { bright, } \\
\text { expanded }\end{array}$ & $\begin{array}{l}\text { collective and } \\
\text { individual: } \\
\text { dissociation }\end{array}$ \\
\hline
\end{tabular}


themselves in what Stathis Kalyvas calls 'the confessional dilemma' and had to figure out 'how to escape from the constraints of their confessional origins while maintaining a distinctive identity' (1996, p. 223).

The role of Christianity for today's Christian-democratic parties is ambivalent and subject to intense internal and external debate. As Andreas Wagner demonstrates, traditional Christian positions on economic policies (aiming at a Christian understanding of a social market economy), welfare (oriented on the malebreadwinner model) or sexuality and gender (e.g. in opposition to gay rights) are controversial even within Christian democratic parties (2014, pp. 211-213). Nowadays, these parties mostly combine groups with different, more liberal, conservative or strictly Christian preferences. Calls for a stronger focus on Christianity-or even just for a reflection on religious foundations-are regularly heard. The central objection against this is the unpopularity of traditional religious arguments for an electorate increasingly unaffiliated to religion (Florin, 2014).

The historical internal dilemma of Christian-democratic parties - to successfully combine a Christian identity with a liberal democratic setting-is highly topical today. Within the field of immigrant integration, however, this dilemma seems to be dissolved by promoting a collective identity that interweaves Christianity with liberal norms against an equally religiously defined other. While religion was always an explicit part of Christiandemocratic ideology, the extent to which it was highlighted and communicated varied. Unlike in other policy fields, the emphasis on Christianity is hardly contested here. Apparently, the outsourcing of a broader value debate to the field of immigrant integration allows Christian-democratic policymakers to both solve their internal dilemma and position a collective identity narrative clearly associated with their parties.

\section{Conclusion}

To conclude, I want to go back to the rhetorical question I raised at the beginning: Are we all Christian, are we all secular, are we all liberal or are we just white? Analysing the construction of religions as symbolic boundaries has allowed assessing the role of religion in the collective identities promoted in German and Austrian immigrant integration policies. To start with the obvious: This analysis supports the well-established claim that liberal norms are a strong, if not the central, element that European collective identities draw on in the context of immigrant integration. The investigated policies correspond to the notion of muscular liberalism as described in the literature. Promoted collective identities are essentially liberal.

Regarding the question whether this liberal collective identity is Christian or secular in character, the analysis found both. As references to religion were the central focus of this study, notions of identity that draw on secularism were not analysed systematically. Here lies great potential for further research that relates theoretical debates on conceptualizations of the secular (e.g. Warner, Van Antwerpen, \& Calhoun, 2010) to an empirical analysis of collective identity constructions. The focus on religion in this empirical analysis, though, clearly showed that Christian and secular values are not set in contradiction, which results in the notion of a 'Christian secular'. If this, as Tariq Modood suggests, is an emerging identity that is Christian but not related to religious practice, the answer to the question if the observed collective identity is Christian or secular is: it is both. Taking into account the observed promotion of a universal religion somewhat changes the picture. Here a vital religiousness, not exclusively limited to Christianity, is promoted and results in a marginalization of the secular and the question becomes even less answerable within the limited scope of this study. These dynamics warrant further comparative research on a larger scale, in particular among countries with distinct experiences in terms of religion-state relations and party political settings.

Together the observed boundaries build a clear hierarchical order based on religion, establishing a superiority of Christianity as marker of Europeanness over Islam as the illiberal other. This analysis shows that religionboth Christianity and Islam - is used to uphold difference. Muslims are constructed as inferior to Christianity and the 'truly' European populations produced by it. This supports Fatima El-Tayeb's argument of Muslim as a racialized category.

The way Christianity gets linked to secular structures, liberal norms and their transmission merges Christianity and the structural and normative foundations of Austrian, German and European societies. Within immigrant integration policies, the contradictions between those ideologies are argumentatively eliminated, often even reversed. The Christian-democratic policymakers who shaped those policies did not aim to promote a Christian identity instead of a liberal one but seem to have succeeded in equating the primarily liberal collective identities promoted within immigrant integration policies with Christianity.

\section{Acknowledgments}

I want to thank Anna Korteweg and Sieglinde Rosenberger for their helpful commentary on previous versions of this paper. This article was supported by the Short-term grant abroad and the Open Access Publishing Fund of the University of Vienna.

\section{Conflict of Interests}

The author declares no conflict of interests.

\section{References}

Adamson, F., Triadafilopoulos, T., \& Zolberg, A. (2011). The limits of the liberal state: Migration, identity and 
belonging in Europe. Journal of Ethnic and Migration Studies, 37(6), 843-859. doi:10.1080/1369183X. 2011.576188

Alba, R. (2005). Bright vs. blurred boundaries: Secondgeneration assimilation and exclusion in France, Germany, and the United States. Ethnic and Racial Studies, 28(1), 20-49. doi:10.1080/0141987042000 280003.

Allievi, S. (2005). How the immigrant has become Muslim. Revue Européenne des Migrations Internationales, 21(2), 135-163. doi:10.4000/remi.2497

Asad, T. (2003). Formations of the secular: Christianity, Islam, modernity. Stanford: Stanford University Press.

Avramopoulou, E., Çorbacioğlu, G., \& Sanna, M. (2012). Thinking through secularism: Debates on the Muslim veil in Europe. In S. Rosenberger \& B. Sauer (Eds.), Politics, religion and gender: Framing and regulating the veil (pp. 37-55) New York: Routledge.

Bail, C. A. (2008). The configuration of symbolic boundaries against immigrants in Europe. American Sociological Review, 73(1), 37-59. doi:10.2307/25472513

Barth, F. (1998). Ethnic groups and boundaries: The social organization of culture difference. Long Grove: Waveland Press.

Beaman, L. (2013). The will to religion: Obligatory religious citizenship. Critical Research on Religion, 1(2), 141-157. doi:10.1177/2050303213490040

Binder, D. (2001). Die österreichische Volkspartei nach 1945. In M. Gehler, W. Kaiser, \& H. Wohnout (Eds.), Christdemokratie in Europa im 20. Jahrhundert (pp. 399-424. Vienna: Böhlau Verlag.

Bommes, M., \& Kolb, H. (2012). Germany. In C. Joppke L. F. \& Seidle (Eds.), Immigrant integration in federal Countries (pp. 113-134). Quebec: MQUP.

Brubaker, R. (2010). Migration, membership, and the modern nation-state: Internal and external dimensions of the politics of belonging. Journal of Interdisciplinary History, 41, 61-78.

Brubaker, R. (2013). Categories of analysis and categories of practice: A note on the study of Muslims in European countries of immigration. Ethnic and Racial Studies, 36(1), 1-8. doi:10.1080/01419870.2012.729674

Bundesministerium für Inneres. (2008). Gemeinsam kommen wir zusammen. Retrieved from http:// www.pakte.at/attach/1gemeinsam_kommen_wir_zu sammen_gesamt.pdf

Bundesministerium für Inneres. (2012). Dialogforum Islam. Öffentliche Sicherheit, 3/4, 24.

Bundesministerium für Inneres. (2013). Dialogforum Islam. Öffentliche Sicherheit, 1/2, 36-37.

Cesari, J. (2009). The two pillars of state regulation of European Islam. In J. Heynes (Ed.), Routledge handbook of religion and politics (pp. 231-248). New York: Routledge.

De Cillia, R., Reisigl, M., \& Wodak, R. (1999). The discursive construction of national identities. Discourse \& Society, 10(2), 149-173. doi:10.1177/09579265990 10002002
Der Spiegel. (2010, October 15). Integration: Seehofer und Merkel befeuern Leitkultur-Debatte. Spiegel Online. Retrieved from http://www.spiegel.de/politik/ deutschland/integration-seehofer-und-merkel-befeu ern-leitkultur-debatte-a-723466.html

Deutsche Bundesregierung. (2007). Der Nationale Integrationsplan Neue Wege-Neue Chancen Deutschland. Retrieved from https://www.bundes regierung.de/Content/DE/Publikation/IB/nationalerintegrationsplan.html

Deutsche Islamkonferenz. (2009). Drei Jahre Deutsche Islamkonferenz (2006-2009): Muslime in Deutschland-Deutsche Muslime. Retrieved from http://gsb.download.bva.bund.de/BAMF/DIK/09061 6_DIK-Broschuere_gesamt_ONLINE.pdf

Die Presse. (2011, August 25). Kurz: 'Eingangsphasen für jedes Studium'. DiePresse.com. Retrieved from http://diepresse.com/home/politik/innenpolitik/688 329/Kurz_Eingangsphasen-fur-jedes-Studium

Dierickx, G. (1994). Christian Democracy and its ideological rivals. In D. Hanley (Ed.), Christian democracy in Europe: A comparative perspective (pp. 15-30) London: A\&C Black.

Dombrowski, D. (2014). Rawls and religion: The case for political liberalism. Albany: SUNY Press.

Eder, K. (2006). Europe's borders: The narrative construction of the boundaries of Europe. European Journal of Social Theory, 9(2), 255-271. doi:10.1177/ 1368431006063345

El-Tayeb, F. (2011) European others: Queering ethnicity in postnational Europe. Minneapolis: University of Minnesota Press.

Florin, C. (2014). Christliche Leitkultur-Das ist vorbei. Christ\&Welt, Nr. 22. Retrieved from http://www. christundwelt.de/detail/artikel/christliche-leitkulturdas-ist-vorbei

Foner, N., \& Alba, R. (2008). Immigrant religion in the U.S. and Western Europe: Bridge or barrier to inclusion? International Migration Review, 42(2), 360392. doi:10.1111/j.1747-7379.2008.00128.x

Gillespie, R. (2014). Reason, religion, and postsecular: Liberal-democratic epistemology. Philosophy \& Rhetoric, 47(1), 1-24. doi:10.5325/philrhet.47.1. 0001

Grillo, R. (2010). British and others: From 'race' to 'faith'. In S. Vertovec \& S. Wessendorf (Eds.), The multiculturalism backlash: European discourses, policies and practices (pp. 50-71) London: Routledge.

Guibernau, M. (2004). Anthony D. Smith on nations and national identity: A critical assessment. Nations and Nationalism, 10(1/2), 125-141. doi:10.1111/j.13545078.2004.00159.x

Habermas, J. (1991). Staatsbürgerschaft und nationale Identität: Überlegungen zur europäischen Zukunft. St. Gallen: Erker.

Hansen, R. (2011). The two faces of liberalism: Islam in contemporary Europe. Journal of Ethnic and Migration Studies, 37(6), 881-897. doi:10.1080/1369183X. 
2011.576192

Joppke, C. (2008). Immigration and the identity of citizenship: The paradox of universalism. Citizenship Studies, 12(6), 533-546. doi:10.1080/13621020802450445

Joppke, C. (2013). A Christian identity for the liberal state? The British Journal of Sociology, 64(4), 597616. doi:10.1111/1468-4446.12041

Kalyvas, S. (1996). The rise of Christian democracy in Europe. Ithaca: Cornell University Press.

Kathpress. (2011, June 9). Kurz: Religionen sind Partner für gelungene Integration. Kathpress.at. Retrieved from https://www3.kathpress.at/goto/meldung/42 3247/kurz-religionen-sind-partner-fuer-gelungene-in tegration

Kommers, D. (2012). The constitutional jurisprudence of the Federal Republic of Germany (3rd ed.). Durham: Duke University Press.

Koopmans, R. (2005). Contested citizenship: Immigration and cultural diversity in Europe. Minneapolis: University of Minnesota Press.

Korteweg, A., \& Triadafilopoulos, T. (2013). Gender, religion, and ethnicity: Intersections and boundaries in immigrant integration policy making. Social Politics: International Studies in Gender, State \& Society, 20(1), 109-136. doi:10.1093/sp/jxs027

Korteweg, A., \& Yurdakul, G. (2014). The headscarf debates: Conflicts of national belonging. Stanford: Stanford University Press.

Laborde, C. (2013). Political liberalism and religion: On separation and establishment. The Journal of Political Philosophy, 21(1), 67-86. doi:10.1111/j.14679760.2011.00404.x

Lamont, M., \& Molnár, V. (2002). The study of boundaries in the social sciences. Annual Review of Sociology, 28(1), 167-195. doi:10.1146/annurev.soc.28. 110601.141107

Laurence, J. (2013). Islam and Social Democrats: Integrating Europe's Muslim minorities. Dissent Magazine. Retrieved from https://www.dissentmagazine.org/ article/islam-and-social-democrats

Maffettone, S. (2014). Why liberalism is more important than secularism. Telos, 2014(167), 88-106. doi:10.3817/0614167088

Manz, S. (2004). Constructing a normative national identity: The 'Leitkultur' debate in Germany, 2000/2001. Journal of Multilingual and Multicultural Development, 25(5/6), 481-496. doi:10.1080/014346304 08668920

Mattes, A., \& Rosenberger, S. (2015). Islam and Muslims in Austria. In I. Michalowski \& M. Burchardt (Eds.), After integration, Islam, conviviality and contentious politics in Europe (pp. 129-152). Wiesbaden: Springer.

Mayring, P. (2008). Qualitative Inhaltsanalyse: Grundlagen und Techniken. Weinheim: Beltz.

Minkenberg, M. (2002). Religion and public policy institutional, cultural, and political Impact on the shaping of abortion policies in western democracies. Compar- ative Political Studies, 35(2), 221-247. doi:10.1177/ 0010414002035002004

Modood, T. (2009). Muslims and the politics of difference. In P. Hopkins \& R. Gale (Eds.), Muslims in Britain: Race, place and identities (pp. 191-209). Edinburgh: Edinburgh University Press.

Modood, T. (2012). Is there a crisis of secularism in Western Europe? Sociology of Religion, 73(2), 130-149. doi:10.1093/socrel/srs028

Müller, J. (2014, June 15). The end of Christian democracy. Foreign Affairs. Retrieved from https://www. foreignaffairs.com/articles/western-europe/2014-0715/end-christian-democracy

Pachucki, M. A., Lamont, M., \& Pendergrass, S. (2007). Boundary processes: Recent theoretical developments and new contributions. Poetics, 35(6), 331351. doi:10.1016/j.poetic.2007.10.001

Rosenow-Williams, K. (2012). Organizing Muslims and integrating Islam in Germany: New developments in the 21st century. Boston: Brill.

Scheffer, P. (2011). The open society and its believers. In M. McTernan (Ed.), Exploring the cultural challenges to social democracy (pp. 61-69) London: The Policy Network.

Schwarze, T. (2010, October 16). Merkel gegen Seehofer: 'Der Islam ist Teil Deutschlands'. $n$-tv.de. Retrieved from http://www.n-tv.de/politik/Der-Islamist-Teil-Deutschlands-article1729166.html

Spielhaus, R. (2011). Wer ist hier Muslim? Die Entwicklung eines islamischen Bewusstseins in Deutschland zwischen Selbstidentifikation und Fremdzuschreibung. Würzburg: Ergon Verlag.

Staatssekretariat für Integration. (2011). Arbeitsprogramm des Expertenrats für Integration. Retrieved from www.bmi.gv.at/cms/cs03documents bmi/957.pdf

Sternberger, D. (1990). Verfassungspatriotismus. Frankfurt am Main: Insel Verlag.

Tibi, B. (1998). Europa ohne Identität? Die Krise der multikulturellen Gesellschaft. Munich: Bertelsmann.

Triadafilopoulos, T. (2011). Illiberal means to liberal ends? Understanding recent immigrant integration policies in Europe. Journal of Ethnic and Migration Studies, 37(6), 861-880. doi:10.1080/1369183X. 2011.576189

Van Hecke, S., \& Gerard, E. (Eds.). (2004). Christian democratic parties in Europe since the end of the cold war. Leuven: Leuven University Press.

Wagner, A. (2014). Wandel und Fortschritt in den Christdemokratien Europas. Wiesbaden: Springer.

Warner M., Van Antwerpen, J., \& Calhoun, C. (Eds.). (2010). Varieties of secularism in a secular age. Cambridge: Harvard University Press.

Wilson, E., \& Mavelli, L. (2014). Faith and the asylum crisis: The role of religion in responding to displacement. Groningen: University of Groningen.

Wimmer, A. (2013). Ethnic boundary making: Institutions, power, networks. Oxford: Oxford University Press. 
Zincone, G., Penninx, R., \& Borkert, M. (Eds.). (2011). Migration policymaking in Europe: The dynamics of actors and contexts in past and present. Amsterdam: Amsterdam University Press.
Zolberg, A., \& Woon, L. L. (1999). Why Islam is like Spanish: Cultural incorporation in Europe and the United States. Politics \& Society, 27(1), 5-38. doi:10.1177/0032329299027001002

\section{About the Author}

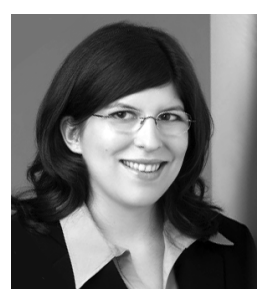

Astrid Mattes is a University Assistant at the Department of Political Science at the University of Vienna. She studied Political Science and Comparative Religious Studies in Vienna and Limerick and spent research visits at the University of Lucerne and the University of Toronto. Her main research interests are European migration and integration politics, religious pluralism, diversity in liberal democracies, and Islam in Europe. 